Arq. Bras. Med. Vet. Zootec., v.70, n.2, p.419-428, 2018

\title{
The use of reduced glutathione (GSH) as antioxidant for cryopreserved sperm in dogs
}

[O uso da glutationa reduzida (GSH) como antioxidante na criopreservação seminal em cães]

D.S.R. Angrimani, M. Nichi, M.M. Brito, G.K.V. Kawai, B.R. Rui, J.D.A. Losano, N.M.G. Vieira, M.C.P. Francischini, D.S.G. Cruz, N. Queiroz-Hazarbassanov, C.O. Massoco, C.I. Vannucchi*

Universidade de São Paulo - São Paulo, SP

\begin{abstract}
The aim of this study was to evaluate the effect of supplementation with different concentrations of reduced glutathione GSH $(0 ; 5 ; 7.5 ; 10 \mathrm{mM})$ in the extender for cryopreservation in dogs with evaluations performed after glycerolization (chilled) and thawing (thawed). For this purpose, we used 8 dogs and two semen collections were performed in a weekly interval, totaling 16 semen samples. The sperm were analyzed by automatic sperm motility (CASA) and flow cytometry analysis of mitochondrial potential (JC1 dye) and membrane/acrosome integrity (FITC-PI dyes). We evaluated subjectively the membrane and acrosome integrity, mitochondrial activity and DNA integrity. Seminal plasma was evaluated for lipid peroxidation (TBARS concentration). Chilled and thawed samples supplemented with 7.5 and $10 \mathrm{mM}$ of GSH had lower percentage of sperm with high (DAB - Class I) and medium (DAB - Class II) mitochondrial activity. And 10mM of GSH had higher percentage of low mitochondrial activity (DAB Class III). Moreover, thawed samples of $10 \mathrm{mM}$ of GSH had high DNA fragmentation rates. Probably by a reductive stress effect on mitochondria which lead to an increase in reactive oxygen species, and a mitochondrial malfunction.
\end{abstract}

Keywords: reactive oxygen species, cryopreservation, antioxidant, canine

\section{RESUMO}

O objetivo deste estudo foi avaliar o efeito da suplementação com diferentes concentrações de glutationa reduzida (GSH - 0; 5; 7,5; 10mM) para criopreservação em cães com avaliações realizadas após glicerolização (refrigeração) e descongelação. Para tal, foram utilizados oito cães e foram realizadas duas coletas de sêmen em intervalo semanal, totalizando 16 amostras de sêmen. Foram avaliadas a motilidade espermática computadorizada (CASA) e a análise de citometria de fluxo do potencial mitocondrial (sonda JC-1) e integridade da membrana/acrossomal (sonda FITC-PI). Subjetivamente foi avaliada a integridade da membrana plasmática e do acrossomal, atividade mitocondrial e integridade do DNA. O plasma seminal foi avaliado quanto à peroxidação lipídica (concentração de TBARS). As amostras refrigeradas e descongeladas suplementadas com 7,5 e 10mM de GSH apresentaram menor porcentagem de espermatozoides com alta atividade mitocondrial (DAB - Classe I) e média (DAB Classe II). Na concentração de $10 \mathrm{mM}$ de GSH, apresentaram maior porcentagem de baixa atividade mitocondrial (DAB - Classe III). Além disso, amostras descongeladas de 10mM de GSH apresentaram taxas de fragmentação de DNA elevadas, provavelmente por efeito de estresse redutivo sobre as mitocôndrias que elevam as espécies reativas de oxigênio e disfunção mitocondrial.

Palavras-chave: espécies reativas ao oxigênio, criopreservação, antioxidante, caninos

\section{INTRODUCTION}

The advances of assisted reproduction techniques in dogs are extremely offset when compared to farm animals (Goodrowe et al., 2000; Luvoni et al., 2005). However nowadays, some reproductive biotechnologies are being highly studied, such as the artificial insemination and semen cryopreservation in canines (Lucio et al., 2016b).

Recebido em 11 de janeiro de 2017

Aceito em 8 de junho de 2017

* Autor para correspondência (corresponding author)

E-mail: cacavann@usp.br 
These efforts occur because the semen cryopreservation allows the preservation and propagation of genetic material, through long distances, even post mortem (Thomassen and Farstad, 2009).

But the process of seminal cryopreservation promotes loss of sperm motility and decrease of survival post-thaw (Belala et al., 2016). Such effects occur mainly through the reactive oxygen species (ROS) generated by the spermatozoa (Goes et al., 2011). In small amounts, ROS promote physiological effects, such as sperm capacitation. On the other hand, in high quantity, ROS can be deleterious to sperm cell, causing oxidative stress (OS) (Aitken, 1997). OS promotes injury in proteins, carbohydrates, plasma membrane, sperm motility, and in spermatic DNA integrity (Birben et al., 2012).

To reduce the effects of ROS during sperm cryopreservation, researches involve an addition of antioxidants agents to extenders (Monteiro et al., 2009; Lucio et al., 2016b). Antioxidants are produced physiologically by organisms, to minimize or prevent the oxidation by ROS effect in a determined substrate (Shi et al., 2013). In dogs, most of the antioxidant defense present in semen are from the seminal plasma, wherein superoxide dismutase (SOD), glutathione peroxidase (GPx), phospholipid hydroperoxide glutathione peroxidase (PHGPx) and reduced glutathione (GSH) were previously identified (Strzezek et al., 2009; Angrimani et al., 2014). The glutathione cycle (i.e. GPx; GSH and PHGPx) combined with SOD had an important effect in ROS combat, because this enzymes catalyse the chain reaction in which superoxide anion $\left(\mathrm{O}^{-}\right)$, the first produced $\mathrm{ROS}$, is converted into water $\left(\mathrm{H}_{2} \mathrm{O}_{2}\right)$ (Cadenas and Davies, 2000). Moreover, glutathione develops an important function in the preservation of membrane integrity against lipid peroxidation, sperm motility and avoid premature acrosome reaction (Alvarez and Storey, 1989; Rejraji et al., 2002; Gadea et al., 2013).

Therefore, antioxidant supplementation (i.e. SOD or GSH) in extender to cryopreservation improves the spermatic quality after thawing (Monteiro et al., 2009). Actually, in humans the supplementation or addition of antioxidant substances presents more promising results when in domestic animals (Kobori et al., 2014;
Kedechi et al., 2017). However, Ogata et al. (2015) observed that sperm cryopreserved using $5 \mathrm{mM}$ of reduced glutathione (GSH) had an increased in motility and higher acrosome integrity. Lucio et al. (2016b) in similar study using $10 \mathrm{mM}$ of GSH described superior acrosome integrity and positive pregnancies in sperm cryopreserved.

Despite the previously studies, there is no consensus about the concentration of GSH that provides better results after thawing or even in chilled semen. Thus, the aim of this study was to evaluate the supplementation with different concentrations of reduced glutathione $(\mathrm{GSH}-0$; $5 ; 7.5 ; 10 \mathrm{mM})$ in the extender for cryopreservation in dogs with evaluations performed after both glycerolization (chilled) and thawing (thawed).

\section{MATERIALS AND METHODS}

The current study was approved by the Bioethics Committee of the School of Veterinary Medicine and Animal Science - University of São Paulo. In this experiment, eight breeder dogs (age from 2 to 7 years) were used. The sperm collection was performed through digital manipulation. All male used in this study showed sperm concentration of $1 \times 10^{9}$ spermatozoa per ejaculate and sperm motility higher than $70 \%$.

The extender used for cooled and cryopreservation was the Tris-citrate egg yolk TEYC; $0.26 \mathrm{M}$ Tris-hydroxymethylaminomethane, $0.14 \mathrm{M}$ citric acid monohydrate, $0.06 \mathrm{M}$ D-fructose, $20 \%$ egg yolk, $0.02 \mathrm{M}$ of gentamicin, and distilled water, $1179 \mathrm{mOsm} / \mathrm{L}$, $\mathrm{pH} 1 / 4$ 6.95). The treatment groups had an addition of an antioxidant supplement with GSH, in different concentrations $(5 \mathrm{mM}, 7.5 \mathrm{mM}$ and $10 \mathrm{mM})$. There were 8 experimental groups: GSH0 (extender without reduced glutathione cooled semen), GSH5 (extender with 5mM of reduced glutathione - cooled semen), GSH7.5 (extender with $7.5 \mathrm{mM}$ of reduced glutathione cooled semen), GSH10 (extender with $10 \mathrm{mM}$ of reduced glutathione - cooled semen), GSH0 (extender with $0 \mathrm{mM}$ of reduced glutathione thawed semen), GSH5 (extender with $5 \mathrm{mM}$ of reduced glutathione - thawed semen), GSH7.5 (extender with $7.5 \mathrm{mM}$ of reduced glutathione thawed semen) and GSH10 (extend with $10 \mathrm{mM}$ of reduced glutathione - thawed semen). 
After collection of semen, only the sperm-rich fraction of the ejaculate was used. The total volume of semen was centrifuged (200æg for 5 minutes) and the supernatant was discarded. After determination of the sperm concentration (spermatozoa $/ \mathrm{ml}$ ) in the hematimetric chamber at the dilution of 1: 200, the diluted semen was divided into 4 equal parts, in order to contemplate the 8 experimental groups. The semen samples were cooled at 5 degrees for 1h30. After that period the semen was divided into two parts, while the cold was evaluated immediately the other part followed the one-step semen cryopreservation protocol (Brito et al., 2016).

The cooled and pos-thaw samples were also evaluated through the techniques of computerized analysis of motility, mitochondrial activity, DNA fragmentation, flow cytometry with evaluation of plasma membrane integrity and membrane acrosomal and mitochondrial membrane potential, and, finally, oxidative stress.

Computer Assisted Sperm Analysis (CASA) was evaluated using the Hamilton-Thorne Ivos 12.3 equipment. For the reading, $10 \mu \mathrm{l}$ were used in counting chamber and 8 fields were randomly selected for analysis of the following variables: VAP $(\mu \mathrm{m} / \mathrm{s})$, VSL $(\mu \mathrm{m} / \mathrm{s})$, VCL $(\mu \mathrm{m} / \mathrm{s})$, ALH $(\mu \mathrm{m})$, BCF $(\mathrm{Hz})$, STR $(\%)$, LIN $(\%)$; MOT $(\%)$, PROG (\%). The spermatozoa were then divided into 4 groups based on the velocity of displacement, which consisted of: Rapid (\% RAP, VAP $>50 \mu \mathrm{m} / \mathrm{s})$, Mean $(30 \mu \mathrm{m} / \mathrm{s}$ VAP $<50 \mu \mathrm{m} / \mathrm{s})(\%$ SLOW, VAP $<30 \mu \mathrm{m} / \mathrm{s}$ or VSL $<15 \mu \mathrm{m} / \mathrm{s})$ and immotile spermatozoa (\% STATIC) (Verstegen et al., 2002).

We assessed sperm mitochondrial activity by means of a cytochemical technique with 3'3 diaminobenzidine stain (DAB assay), which is oxidized by the cytochrome c enzyme and forms a brown colored complex that is deposited on active mitochondria (Hrudka, 1987). Briefly, $20 \mu \mathrm{L}$ of semen was incubated with $20 \mu \mathrm{L}$ of 3'3 diaminobenzidine in an amber microcentrifuge tube for 1 hour in water bath at $37^{\circ} \mathrm{C}$.

After incubation, the mixture was smeared on microscopy slides in dark ambient. Slides were subsequently fixed in $10 \%$ formaldehyde for 10 minutes. Analysis was performed in phase contrast microscopy at $1000 \mathrm{x}$ magnification under immersion oil. One hundred cells were counted and classified into 4 classes according to the percentage of stained midpiece: completely stained, indicating high mitochondrial activity (DAB I); more than $50 \%$ of the midpiece stained, indicating medium activity (DAB II); less than $50 \%$ of the mid-piece stained, indicating low activity (DAB III); and midpiece completely unstained, indicating absence of mitochondrial activity (DAB IV).

For the DNA fragmentation analysis, the toluidine blue staining technique was used (Flores et al., 2016). In this way, the semen smears were fixed in the $96 \%$ alcohol solution and acetone $(1: 1)$ at $4^{\circ} \mathrm{C}$ for 30 minutes. The smears were then dried for 30 minutes and then introduced into acid solution of $\mathrm{HCl}(0.1 \mathrm{~N})$ at $4^{\circ} \mathrm{C}$ for 5 minutes for cell hydrolysis. The slides were then washed three times in distilled water for 2 minutes. After washing, the slides were stained in toluidine blue solution $(0.05 \%)$ for 20 minutes. Finally, the slides were washed twice in distilled water for two minutes and after drying at room temperature, the reading was performed under a light microscope under immersion objective, with a count of 200 spermatozoa. Results were expressed as percentage (\%).

For the semen viability tests, the flow cytometry technique was used in the BD FACSCalibur (Becton Dickinson, East Rutherford, NJ, USA) with the use of fluorescent probes. The probes used were previously validated for canine semen. For each probe, 118,000 cells were considered.

To evaluate the plasma membrane integrity, the propidium iodide fluorescence probe $(\mathrm{PI})$, at a concentration of $6 \mu \mathrm{M}$, diluted in $200 \mu \mathrm{l}$ TALP, was used to penetrate cells with changes in the permeability of the plasma membrane, staining them in Red (Celeghini et al., 2007). For the evaluation of the acrosomal integrity, $5 \mu$ of the fluorescent probe Psium sativum conjugated to fluorescein isothiocyanate (FITC-PSA) at a concentration of $100 \mu \mathrm{g} / \mathrm{ml}$, diluted in $1995 \mu \mathrm{l}$ of $1 \%$ Sodium Azide, was used to stain the injured acrosomes in (Celeghini et al., 2007). Thus, $11.2 \mu \mathrm{l}$ of PI, at the concentration $6 \mu \mathrm{M}$ in the solution of FITC-PSA in 1\% Sodium Azide was added. Then the volume of 188,000 diluted spermatozoa in $37.5 \mu \mathrm{l}$ of TALP was incubated at $37^{\circ} \mathrm{C}$ for 5 minutes in $13 \mu \mathrm{l}$ of the FITC-PI 
solution. Subsequently, $300 \mu 1$ of TALP was added for the sample to be processed on the flow cytometer. This procedure was performed with the aim of obtaining the combined result between plasma and acrosomal membrane integrity of the same cell population. Furthermore, the appropriate controls for the compensation of the probes were used separately, as well as samples with no dye (white) so that it could properly separate the location of the spermatozoa in the graph.

JC-1 $\quad\left(5,5^{\prime}, \quad 6,6^{\prime} \quad\right.$ tetrachloro-1,1,3,3'tetraethylbenzimidazolylcarbocyanine iodide) was the fluorescent probe of choice for the evaluation of the mitochondrial potential of spermatozoa, classifying them as high membrane potential Mitochondrial (orange fluorescence) and low potential (green fluorescence). For this analysis, $1 \mu \mathrm{l}$ of the $\mathrm{JC}-1$ probe was added at a concentration of $50 \mu \mathrm{g} / \mathrm{ml}$ in 188,000 diluted spermatozoa in $37.5 \mu 1$ TALP.

The samples were incubated at $37^{\circ} \mathrm{C}$ for 10 minutes and then $300 \mu l$ of TALP were added, then the sample was processed on the flow cytometer. Spermatozoa were separated into two populations, which contained medium-high mitochondrial potential and low mitochondrial potential.

Analysis of the induced oxidative stress followed by the protocol described by Nichi et al. (2007). $(125 \mu \mathrm{l}, 4 \mathrm{mM})$ and sodium ascorbate $(125 \mu \mathrm{l}$, $20 \mathrm{mM}$ ) for 1.5 hours at $37^{\circ} \mathrm{C}$. For this purpose, $0.5 \mathrm{ml}$ of pre-prepared suspension containing $1 \times 10^{6}$ spermatozoa/ml in TALP was incubated with ferrous sulfate $(125 \mu \mathrm{l}, 4 \mathrm{mM})$. Thereafter, $10 \%$ TCA was added at $4{ }^{\circ} \mathrm{C}$ and a centrifuged mixture (18000xg, 15 minutes) was added to promote a precipitation of proteins and cell debris. Concentration analysis of malondialdehyde (MDA), product of lipid peroxidation. To do this, $500 \mu \mathrm{L}$ of the sample was diluted in $500 \mu 1$ of $1 \%$ thiobarbituric acid and kept in a $100^{\circ} \mathrm{C}$ water bath for 15 minutes and then cooled on ice $\left(0^{\circ} \mathrm{C}\right)$. Thiobarbituric acid reactive substances (TBARS) were quantified by spectrophotometry at $532 \mathrm{~nm}$ wavelength (UVvis Spectrophotometer Ultrospec 3300 Pro, Biochrom Ltd., Cambridge, UK). The results were expressed as TBARS $/ 10^{6}$ spermatozoa).
All data were evaluated using the SAS System for Windows (SAS Institute Inc., Cary, NC, USA). The response variables were evaluated using Guide Data Analyses regarding the residues normality and homogeneity of the variances. For those who did not obey these premises, transformations were made. The effects of the different treatments on time were determined by PROC GLM. Differences between treatments and times were evaluated by parametric method (LSD test). Spearman's correlation was used to calculate the relationship between the results of the samples in the different treatments separately. The probability value was considered as $\mathrm{P}<0.05$. The results were described by means of their untransformed means \pm the standard errors of the means (EPM).

\section{RESULTS}

The results were divided into two experiments, constituting the evaluation of GSH treatments in chilled and post-thawed dog sperm. No statistical difference was observed between the different concentrations of GSH in refrigerated semen for all CASA variables (Table 1), lipid peroxidation, DNA integrity (Table 2) and all flow cytometry variables (Table 3 ).

Significant differences were observed for DAB I, DAB II, and DAB III variables (Figure 1). For these variables, treatments $0 \mathrm{mM}$ and $5 \mathrm{mM}$ did not obtain any difference among them, but had different results between $7.5 \mathrm{mM}$ and $10 \mathrm{mM}$. These results show that the mitochondrial activity of the $0 \mathrm{mM}$ and $5 \mathrm{mM}$ groups was superior to the other treatments. Moreover, the $10 \mathrm{mM}$ treatment was even more deleterious for mitochondrial activity than $7.5 \mathrm{mM}$ group.

Regarding the correlation analysis for chilled sperm we verified a negative correlation between lipid peroxidation and mitochondrial membrane potential $(\mathrm{r}=-0.64, \mathrm{P}=0.0021)$.

As the results of the chilled sperm, no statistical difference was observed between the different concentrations of GSH in post-thawed semen for all CASA variables (Table 4), lipid peroxidation (Table 5) and all flow cytometry variables (Table 6). 
The use of reduced...

Table 1. Effect of different concentrations of GSH $(0,5,7.5$ and $10 \mathrm{mM})$ on the variables evaluated by computer assisted sperm analysis (CASA) in chilled dog semen $(\mathrm{n}=5)$

\begin{tabular}{ccccc} 
& 0mM GSH & $5 \mathrm{mM} \mathrm{GSH}$ & $7.5 \mathrm{mM} \mathrm{GSH}$ & $10 \mathrm{mM} \mathrm{GSH}$ \\
\hline VAP $(\mu \mathrm{m} / \mathrm{s})$ & $71.78 \pm 6.67$ & $77.82 \pm 8.65$ & $69.02 \pm 8.26$ & $73.72 \pm 10.11$ \\
VSL $(\mu \mathrm{m} / \mathrm{s})$ & $57.60 \pm 5.65$ & $60.86 \pm 7.11$ & $56.26 \pm 7.43$ & $58.80 \pm 8.68$ \\
VCL $(\mu \mathrm{m} / \mathrm{s})$ & $106.26 \pm 9.41$ & $117.54 \pm 9.96$ & $101.78 \pm 11.22$ & $110.22 \pm 11.75$ \\
ALH $(\mu \mathrm{m})$ & $5.00 \pm 0.48$ & $5.58 \pm 0.31$ & $5.00 \pm 0.70$ & $5.70 \pm 0.33$ \\
BCF $(\mathrm{Hz})$ & $30.98 \pm 1.59$ & $31.38 \pm 1.90$ & $30.52 \pm 2.17$ & $29.52 \pm 2.50$ \\
STR $(\%)$ & $79.20 \pm 2.22$ & $76.60 \pm 1.99$ & $79.00 \pm 3.61$ & $77.40 \pm 1.60$ \\
LIN $(\%)$ & $55.40 \pm 4.82$ & $52.20 \pm 4.12$ & $55.80 \pm 6.28$ & $53.00 \pm 3.45$ \\
Motility (\%) & $71.20 \pm 6.26$ & $82.60 \pm 6.56$ & $78.60 \pm 8.38$ & $73.80 \pm 13.39$ \\
Progressive (\%) & $43.00 \pm 8.85$ & $47.40 \pm 8.71$ & $47.40 \pm 10.04$ & $43.60 \pm 12.95$ \\
Rapid $(\%)$ & $57.60 \pm 10.13$ & $67.60 \pm 11.69$ & $59.60 \pm 13.00$ & $58.60 \pm 17.22$ \\
Medium (\%) & $13.60 \pm 4.15$ & $15.00 \pm 5.81$ & $19.00 \pm 4.48$ & $15.20 \pm 3.99$ \\
Slow $(\%)$ & $19.20 \pm 4.88$ & $11.00 \pm 4.54$ & $14.60 \pm 5.30$ & $16.80 \pm 8.12$ \\
Static $(\%)$ & $9.60 \pm 2.04$ & $6.00 \pm 2.90$ & $6.80 \pm 3.12$ & $9.60 \pm 5.39$ \\
\hline
\end{tabular}

Table 2. Effect of different GSH concentrations $(0,5,7.5$ and $10 \mathrm{mM})$ on sperm susceptibility to lipid peroxidation (TBARS), mitochondrial activity (DAB) and DNA integrity in chilled dog semen $(n=5)$

\begin{tabular}{ccccc}
\hline & $0 \mathrm{mM} \mathrm{GSH}$ & $5 \mathrm{mM} \mathrm{GSH}$ & $7.5 \mathrm{mM} \mathrm{GSH}$ & $10 \mathrm{mM} \mathrm{GSH}$ \\
\hline TBARS (ng/106) & $201.08 \pm 19.63$ & $225.02 \pm 45.16$ & $223.44 \pm 34.94$ & $219.26 \pm 26.01$ \\
DABI (\%) & $81.60 \pm 3.47 \mathrm{a}$ & $75.80 \pm 6.76 \mathrm{ab}$ & $54.60 \pm 6.55 \mathrm{bc}$ & $48.60 \pm 10.49 \mathrm{c}$ \\
DABII (\%) & $11.80 \pm 1.07 \mathrm{a}$ & $18.40 \pm 5.75 \mathrm{ab}$ & $31.60 \pm 3.88 \mathrm{~b}$ & $31.00 \pm 6.28 \mathrm{~b}$ \\
DABIII (\%) & $2.00 \pm 0.71 \mathrm{a}$ & $1.80 \pm 1.07 \mathrm{a}$ & $2.80 \pm 1.62 \mathrm{a}$ & $8.00 \pm 2.21 \mathrm{~b}$ \\
DABIV (\%) & $4.60 \pm 3.63$ & $4.00 \pm 2.66$ & $11.00 \pm 3.11$ & $12.40 \pm 4.18$ \\
DNA integrity (\%) & $93.20 \pm 3.69$ & $95.80 \pm 1.88$ & $95.60 \pm 2.38$ & $87.80 \pm 4.66$ \\
\hline
\end{tabular}

a,b,c: Different letters on the same line indicate statistical differences between treatments $(\mathrm{P}<0.05)$.

Table 3. Effect of different GSH concentrations $(0,5,7.5$ and $10 \mathrm{mM})$ on the mitochondrial membrane potential and plasma and acrosomal membranes integrity measured by flow cytometry in chilled dog semen $(n=5)$

\begin{tabular}{ccccc}
\hline & $0 \mathrm{mM} \mathrm{GSH}$ & $5 \mathrm{mM} \mathrm{GSH}$ & $7.5 \mathrm{mM} \mathrm{GSH}$ & $10 \mathrm{mM} \mathrm{GSH}$ \\
\hline MIAI (\%) & $75.50 \pm 5.64$ & $65.04 \pm 6.35$ & $69.34 \pm 6.65$ & $67.22 \pm 6.31$ \\
MIAD (\%) & $5.75 \pm 2.57$ & $13.46 \pm 2.30$ & $7.42 \pm 1.81$ & $8.65 \pm 4.17$ \\
MDAI (\%) & $11.70 \pm 4.60$ & $10.89 \pm 3.24$ & $14.68 \pm 4.63$ & $13.15 \pm 4.04$ \\
MDAD (\%) & $7.04 \pm 2.59$ & $10.60 \pm 5.33$ & $8.58 \pm 2.40$ & $10.99 \pm 4.91$ \\
HMMP (\%) & $63.92 \pm 8.15$ & $70.12 \pm 5.59$ & $72.70 \pm 3.30$ & $64.32 \pm 6.60$ \\
IMMP(\%) & $6.54 \pm 3.53$ & $9.77 \pm 4.06$ & $8.03 \pm 3.85$ & $4.93 \pm 2.06$ \\
LMMP (\%) & $24.30 \pm 5.59$ & $16.39 \pm 3.92$ & $15.23 \pm 3.01$ & $25.64 \pm 4.88$ \\
\hline
\end{tabular}

MIAI: membrane integrity and acrosome integrity; MIAD: membrane integrity and acrosome damaged; MDAI: damaged membrane and acrosome integrity; MDAD: Injured membrane and injured acrosome; HMMP: high mitochondrial membrane potential; IMMP: intermediate mitochondrial membrane potential; LMMP: low mitochondrial membrane potential 

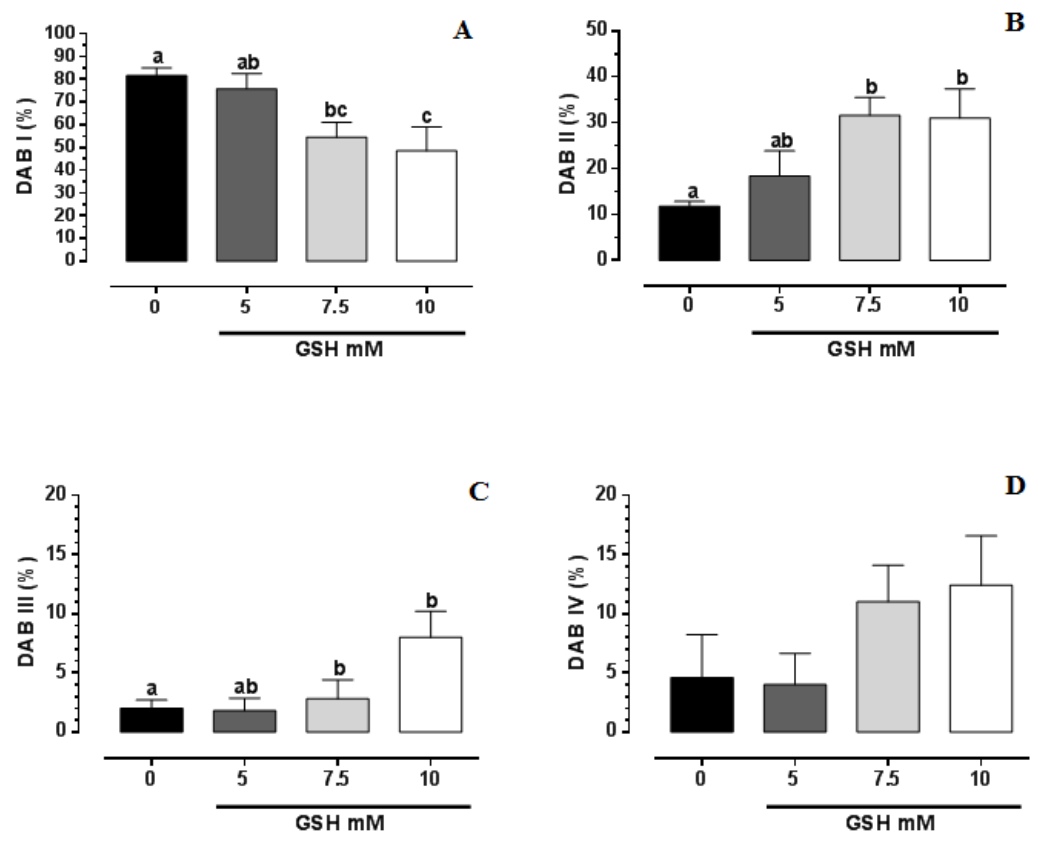

Figure 1. Effect of the GSH treatments on the percentage of cells with high (DAB I, A), intermediate (DAB II, B), low (DAB III, C) and absence of mitochondrial activity (DAB IV, D) in dog chilled sperm. $a, b, c$ : Different letters indicate statistical differences between treatments $(\mathrm{P}<0.05)$.

Table 4. Effect of different GSH concentrations $(0,5,7.5$ and $10 \mathrm{mM})$ on the variables evaluated by computerized analysis of spermatozoa (CASA) in dog post-thawed sperm $(n=5)$

\begin{tabular}{ccccc} 
& 0mM GSH & $5 \mathrm{mM} \mathrm{GSH}$ & $7.5 \mathrm{mM} \mathrm{GSH}$ & $10 \mathrm{mM} \mathrm{GSH}$ \\
\hline VAP $(\mu \mathrm{m} / \mathrm{s})$ & $63.78 \pm 4.38$ & $64.84 \pm 5.69$ & $59.04 \pm 7.60$ & $57.40 \pm 6.81$ \\
VSL $(\mu \mathrm{m} / \mathrm{s})$ & $51.42 \pm 3.64$ & $52.96 \pm 5.45$ & $47.62 \pm 8.06$ & $45.58 \pm 6.71$ \\
VCL $(\mu \mathrm{m} / \mathrm{s})$ & $104.58 \pm 8.57$ & $107.68 \pm 9.10$ & $95.88 \pm 9.73$ & $95.16 \pm 12.42$ \\
ALH $(\mu \mathrm{m})$ & $6.30 \pm 0.68$ & $6.10 \pm 0.50$ & $4.78 \pm 1.21$ & $5.02 \pm 1.34$ \\
BCF $(\mathrm{Hz})$ & $28.96 \pm 1.29$ & $29.70 \pm 2.64$ & $22.04 \pm 5.51$ & $29.44 \pm 0.65$ \\
STR $(\%)$ & $77.40 \pm 2.16$ & $77.80 \pm 3.09$ & $74.40 \pm 5.16$ & $73.40 \pm 3.53$ \\
LIN (\%) & $50.80 \pm 2.99$ & $50.00 \pm 3.18$ & $36.60 \pm 10.97$ & $47.40 \pm 3.20$ \\
Motility (\%) & $44.40 \pm 9.91$ & $37.60 \pm 10.25$ & $36.60 \pm 10.97$ & $31.00 \pm 8.99$ \\
Progressive (\%) & $23.80 \pm 6.37$ & $21.20 \pm 5.93$ & $20.00 \pm 5.68$ & $15.40 \pm 4.48$ \\
Rapid (\%) & $29.40 \pm 7.65$ & $25.20 \pm 7.28$ & $22.80 \pm 6.70$ & $18.20 \pm 5.38$ \\
Medium (\%) & $15.00 \pm 2.85$ & $12.20 \pm 3.61$ & $13.80 \pm 4.40$ & $12.80 \pm 3.88$ \\
Slow (\%) & $20.20 \pm 1.02$ & $14.60 \pm 3.31$ & $24.20 \pm 6.81$ & $32.00 \pm 8.44$ \\
Static (\%) & $35.40 \pm 9.46$ & $48.00 \pm 13.03$ & $39.20 \pm 16.83$ & $36.80 \pm 15.21$ \\
\hline
\end{tabular}

Table 5. Effect of different GSH concentrations $(0,5,7.5$ and $10 \mathrm{mM})$ on sperm susceptibility to lipid peroxidation (TBARS), mitochondrial activity (DNA) and DNA integrity in post-thawed dog sperm $(\mathrm{n}=5)$

\begin{tabular}{ccccc} 
& 0mM GSH & $5 \mathrm{mM} \mathrm{GSH}$ & $7.5 \mathrm{mM} \mathrm{GSH}$ & $10 \mathrm{mM} \mathrm{GSH}$ \\
\hline TBARS (ng/106) & $2330.93 \pm 197.57$ & $2194.84 \pm 229.67$ & $2315.52 \pm 190.63$ & $2406.47 \pm 166.54$ \\
DABI (\%) & $59.60 \pm 9.64 \mathrm{a}$ & $40.80 \pm 9.39 \mathrm{ab}$ & $27.20 \pm 7.57 \mathrm{~b}$ & $22.40 \pm 8.61 \mathrm{~b}$ \\
DABII (\%) & $33.60 \pm 9.10$ & $55.00 \pm 8.12$ & $57.60 \pm 4.27$ & $57.00 \pm 5.17$ \\
DABIII (\%) & $3.40 \pm 2.46$ & $2.20 \pm 1.02$ & $8.40 \pm 3.08$ & $1.40 \pm 0.75$ \\
DABIV (\%) & $2.60 \pm 1.89 \mathrm{a}$ & $2.00 \pm 0.71 \mathrm{a}$ & $6.20 \pm 1.93 \mathrm{a}$ & $19.20 \pm 7.19 \mathrm{~b}$ \\
DNA integrity (\%) & $96.00 \pm 2.00 \mathrm{a}$ & $94.80 \pm 2.15 \mathrm{a}$ & $73.50 \pm 7.03 \mathrm{a}$ & $56.40 \pm 11.13 \mathrm{~b}$ \\
\hline
\end{tabular}

a.b.c: Different letters on the same line indicate statistical differences between treatments $(\mathrm{P}<0.05)$. 
The use of reduced...

Table 6. Effect of different GSH concentrations $(0,5,7.5$ and $10 \mathrm{mM})$ on mitochondrial membrane potential and plasma membrane and acrosomal membranes integrity measured by flow cytometry in post-thawed dog sperm $(n=5)$

\begin{tabular}{ccccc} 
& 0mM GSH & $5 \mathrm{mM} \mathrm{GSH}$ & $7.5 \mathrm{mM} \mathrm{GSH}$ & $10 \mathrm{mM} \mathrm{GSH}$ \\
\hline MIAI (\%) & $27.24 \pm 9.50$ & $31.66 \pm 6.40$ & $30.08 \pm 7.44$ & $30.56 \pm 8.64$ \\
MIAD (\%) & $1.62 \pm 0.73$ & $13.30 \pm 12.30$ & $1.54 \pm 0.44$ & $1.34 \pm 0.18$ \\
MDAI (\%) & $20.12 \pm 2.78$ & $22.32 \pm 3.11$ & $23.32 \pm 3.89$ & $26.82 \pm 4.58$ \\
MDAD (\%) & $51.02 \pm 10.63$ & $32.77 \pm 7.73$ & $45.06 \pm 8.80$ & $41.24 \pm 9.23$ \\
HMMP (\%) & $25.66 \pm 9.10$ & $26.09 \pm 7.34$ & $27.31 \pm 7.46$ & $26.91 \pm 7.51$ \\
IMMP(\%) & $3.71 \pm 0.59$ & $3.22 \pm 0.63$ & $3.12 \pm 0.14$ & $4.41 \pm 1.34$ \\
LMMP (\%) & $60.10 \pm 9.81$ & $55.14 \pm 5.68$ & $59.54 \pm 6.72$ & $56.56 \pm 7.69$ \\
\hline
\end{tabular}

MIAI: membrane integrity and acrosome integrity; MIAD: membrane integrity and acrosome damaged; MDAI: damaged membrane and acrosome integrity; MDAD: Injured membrane and injured acrosome; HMMP: high mitochondrial membrane potential; IMMP: intermediate mitochondrial membrane potential; LMMP: low mitochondrial membrane potential

On the other hand, statistical differences were observed for DNA Integrity, DAB I (Figure 2A), and DAB IV (Figure 2D) variables. For DAB I, the $0 \mathrm{mM}$ and $5 \mathrm{mM}$ treatments did not show any differences. Nonetheless, 0mM was different from $7.5 \mathrm{mM}$ and $10 \mathrm{mM}$. As for DAB IV (Figure $2 \mathrm{D})$, only $10 \mathrm{mM}$ differed from the other treatments. These values show that the mitochondrial activity of the treatments $0 \mathrm{mM}$ and $5 \mathrm{mM}$ did not differ, however the $10 \mathrm{mM}$ treatment was the most deleterious. Regarding the DNA integrity results, the $10 \mathrm{mM}$ treatment was more deleterious than other groups (Figure 3).
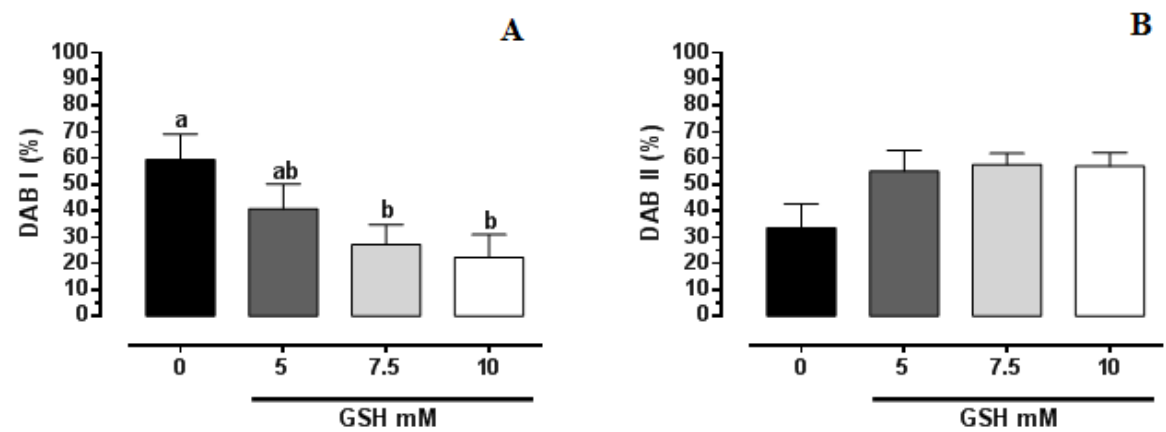

C

D
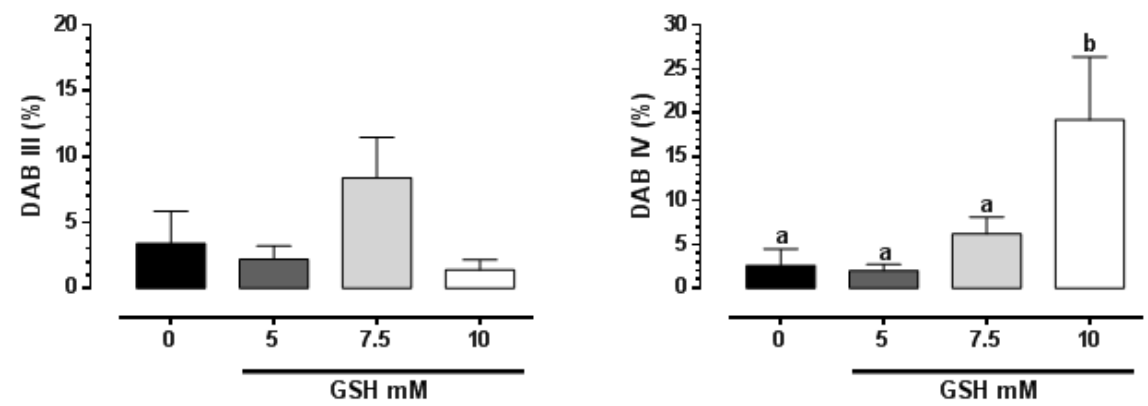

Figure 2. Effect of the GSH treatments on the percentage of cells with high (DAB I, A), intermediate (DAB II, B), low (DAB III, C) and absence of mitochondrial activity (DAB IV, D) in dog post-thawed sperm.

a.b.c: Different letters indicate statistical differences between treatments $(\mathrm{P}<0.05)$. 


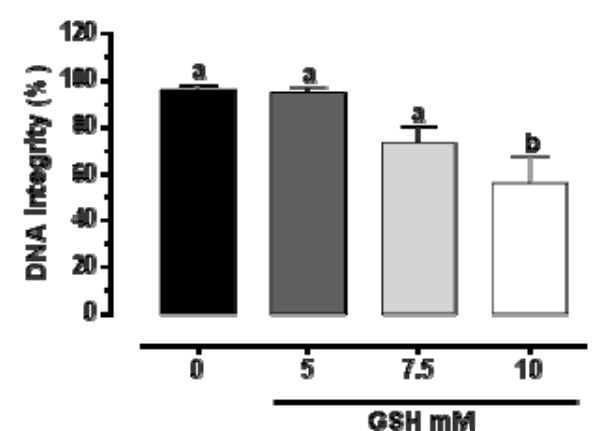

Figure 3. Effect of the GSH treatments on sperm DNA integrity assessed by toluidine blue stain in dog post- thawed sperm.

a.b: Different letters indicate statistical differences between treatments $(\mathrm{P}<0.05)$.

\section{DISCUSSION}

In the present study was evaluated the effect of supplementation with reduced glutathione (GSH) in different concentrations $(0 ; 5 ; 7.5 ; 10 \mathrm{mM})$ in the extender for cryopreservation for dogs. We performed the seminal analysis after glycerolization (chilled) and thawing (thawed).

Our data showed any improvement in seminal parameters in chilled or thawed samples, in all different concentrations of GSH $(5 ; 7.5 ; 10 \mathrm{mM})$. But, it was possible to observed a similar effect between control and $5 \mathrm{mM}$ of GSH group in chilled and thawed samples on high mitochondrial activity (DAB - Class I) and medium mitochondrial activity (DAB - Class II. only in chilled samples) analyzed by the cytochemical technique of 3.3' diaminobenzidine. These results show that control and GSH in $5 \mathrm{mM}$ concentration promotes a better mitochondrial functionality which can reflect in an increased in motility rates and may improve pregnancy, such as previously described (Ogata et al., 2015). Thus, despite our motility results (by CASA) show no changes, this parameter should be better investigated in futures studies.

Furthermore, our data in chilled semen shows a decrease on percentage of high (DAB - Class I) and medium (DAB - Class II) mitochondrial activity in concentrations of $7.5 \mathrm{mM}$ and $10 \mathrm{mM}$ of GSH. Also, $10 \mathrm{mM}$ concentration shows an elevation on percentage of low mitochondrial activity (DAB - Class III). Therefore, we hypothesize that such results demonstrate a reductive stress effect by the excess of antioxidants used (Dawson et al., 1993). A reductive stress effect on mitochondria may lead to an increase in reactive oxygen species, and a mitochondrial malfunction. culminating in dysfunctions in ATP synthesis (Korge and Weiss, 2014). Thus, it is possible to observe negative effects, such as, toxic dose-dependent effect of GSH (7.5 and $10 \mathrm{mM})$ similar to this study. In fact, Lucio et al. (2016b) described a toxic effect of reduced glutathione in a concentration of $20 \mathrm{mM}$, which promoted a higher percentage of sperm with low mitochondrial activity and consequently a greatest generation of free radicals (Blumer et al., 2008; Blumer et al., 2012).

Similar to these results in chilled semen, our data from thawed semen showed the lowest levels of high mitochondrial activity in the groups 7.5 and $10 \mathrm{mM}$ of $\mathrm{GSH}$, and a higher percentage of absence of mitochondrial activity in the concentration of $10 \mathrm{mM}$ of GSH. Lucio et al. (2016a) described that the changes in spermatozoa by the effects of cryopreservation begins during chilled and continues until thawed mainly by production of free radicals, which may occur due to mitochondrial dysfunctions, possibly in our study, by reductive stress (Korge and Weiss, 2014). Despite our results showed no changes in TBARS, it was possible to observe this injurious relationship between mitochondria and oxidative stress in the negative correlation of TBARS and high mitochondrial potential.

Additionally, our data showed a lower DNA integrity in samples supplemented with $10 \mathrm{mM}$ of GSH after thawed. This result may occur as a consequence of mitochondrial dysfunctions, which promotes a DNA fragmentation as described previously in bulls (Gurler et al., 2016) and boars (Guo et al., 2017).

\section{CONCLUSION}

In conclusion, these results show a toxic dosedependent effect of GSH (7.5 and 10mM) in chilled and thawed spermatozoa. However, more studies are necessary, searching the ideal concentration of GSH in each condition, and maybe using associations of other antioxidants (i.e. glutathione peroxidase). 


\section{REFERENCES}

AITKEN, R.J. Molecular mechanisms regulating human sperm function. Mol. Hum. Reprod., v.3, p.169-173, 1997.

ALVAREZ, J.G.; STOREY, B.T. Role of glutathione peroxidase in protecting mammalian spermatozoa from loss of motility caused by spontaneous lipid peroxidation. Gamete Res., v.23, p.77-90, 1989.

ANGRIMANI, D.S.; LUCIO, C.F.; VEIGA, G.A. et al. Sperm maturation in dogs: sperm profile and enzymatic antioxidant status in ejaculated and epididymal spermatozoa. Andrologia, v.46, p.814-819, 2014.

BELALA, R.; BRIAND-AMIRAT, L.; VINCIGUERRA, L. et al. Effect of equilibration time on the motility and functional integrity of canine spermatozoa frozen in three different extenders. Res.Vet. Sci., v.106, p.66-73, 2016.

BIRBEN, E.; SAHINER, U.M.; SACKESEN, C. et al. Oxidative stress and antioxidant defense. World Allergy Org. J., v.5, p.9-19, 2012.

BLUMER, C.G.; FARIELLO, R.M.; RESTELLI, A.E. et al. Sperm nuclear DNA fragmentation and mitochondrial activity in men with varicocele. Fertil. Steril., v.90, p.17161722, 2008.

BLUMER, C.G.; RESTELLI, A.E.; GIUDICE, P.T. et al. Effect of varicocele on sperm function and semen oxidative stress. Bju Int., v.109, p.259-265, 2012.

BRITO, M.M.; LUCIO, C.F.; ANGRIMANI, D.S. et al. Comparison of cryopreservation protocols (single and two-steps) and thawing (fast and slow) for canine sperm. Anim. Biotechnol., v.28, p.1-7, 2016.

CADENAS, E.; DAVIES, K.J. Mitochondrial free radical generation, oxidative stress, and aging. Free Radic. Biol. Med., v.29, p.222-230, 2000 .

CELEGHINI, E.C.C.; DE ARRUDA, R.P.; ANDRADE, A.F.C.; NASCIMENTO, J.; RAPHAEL, C.F. Practical Techniques for Bovine Sperm Simultaneous Fluorimetric Assessment of Plasma, Acrosomal and Mitochondrial Membranes. Reproduction in Domestic Animals. V.42, p. 479 - 488,2007.
DAWSON, T.L.; GORES, G.J.; NIEMINEN, A.L. et al. Mitochondria as a source of reactive oxygen species during reductive stress in rat hepatocytes. Am. J. Physiol., v.264, p.C961C967, 1993.

FLORES, R.B.; ANGRIMANI, D.S.R., RUI, B.R.; BRITO, M.M.; ABREU, R.A.; VANNUCCHI, C.I. The influence of benign prostatic hyperplasia on sperm morphological features and sperm DNA integrity in dogs. Reproduction in Domestic Animals, v 52, p. 310 $-315,2017$.

GADEA, J.; GUMBAO, D.; GOMEZGIMENEZ, B.; GARDON, J.C. Supplementation of the thawing medium with reduced glutathione improves function of frozen-thawed goat spermatozoa. Reprod. Biol., v.13, p.24-33, 2013.

GOES, P.A.A.; NICHI, M.; SILVA, R.O.C. et al. Influence of cryopreservation on the susceptibility of goat sperm against different reactive oxygen species. Reprod. Fertil. Develop., 23, 143-143, 2011.

GOODROWE, K.L.; WALKER, S.L.; RYCKMAN, D.P. et al. Piecing together the puzzle of carnivore reproduction. Anim. Reprod. Sci., v.60-61, p.389-403, 2000.

GUO, H.; GONG, Y.; HE, B.; ZHAO, R. Relationships between mitochondrial DNA content, mitochondrial activity, and boar sperm motility. Theriogenology, v.87, p.276-283, 2017.

GURLER, H.; MALAMA, E., HEPPELMANN, M. et al. Effects of cryopreservation on sperm viability, synthesis of reactive oxygen species, and DNA damage of bovine sperm. Theriogenology, v.86, p.562-571, 2016.

KEDECHI, S.; ZRIBI, N.; LOUATI, N. et al. Antioxidant effect of hydroxytyrosol on human sperm quality during in vitro incubation. Andrologia, v.49, p1 -5 2017.

KOBORI, Y.; OTA, S.; SATO, R. et al. Antioxidant cosupplementation therapy with vitamin $\mathrm{C}$, vitamin $\mathrm{E}$, and coenzyme Q10 in patients with oligoasthenozoospermia. Arch. Ital. Urol. Androl., v.86, p.1-4, 2014.

KORGE, P.; WEISS, J.N. Reductive stress increases reactive oxygen species production in cardiac mitochondria: a key role of thioredoxin reductase. Biophys J. v.106, p.184a, 2014. 
LUCIO, C.F.; REGAZZI, F.M.; SILVA, L.C. et al. Oxidative stress at different stages of two-step semen cryopreservation procedures in dogs. Theriogenology, v.85, p.1568-1575, 2016a.

LUCIO, C.F.; SILVA, L.C.; REGAZZI, F.M. et al. Effect of reduced glutathione (GSH) in canine sperm cryopreservation: In vitro and in vivo evaluation. Cryobiology, v.72, p.135-140, 2016 b.

LUVONI, G.C.; CHIGIONI, S.; ALLIEVI, E.; MACIS, D. Factors involved in vivo and in vitro maturation of canine oocytes. Theriogenology, v.63, p.41-59, 2005.

MONTEIRO, J.C.; GONCALVES, J.S.; RODRIGUES, J.A. et al. Influence of ascorbic acid and glutathione antioxidants on frozenthawed canine semen. Reprod. Domest. Anim. Zuchthyg., v.44, Suppl.2, p.359-362, 2009.

NICHI, M.; GOOVAERTS, I.G.F.; CORTADA, C.N.M.; BARNABE, V.H.; DE CLERCQ, J.B.P.; BOLS, P.E.J. Roles of lipid peroxidation and cytoplasmic droplets on in vitro fertilization capacity of sperm collected from bovine epididymides stored at 4 and $34^{\circ} \mathrm{C}$. Theriogenology. V. 67, p. $334-340,2007$.

OGATA, K.; SASAKI, A.; KATO, Y. et al. Glutathione supplementation to semen extender improves the quality of frozen-thawed canine spermatozoa for transcervical insemination. $J$. Reprod. Dev., v.61, p.116-122, 2015.
REJRAJI, H.; VERNET, P.; DREVET, J.R. GPX5 is present in the mouse caput and cauda epididymidis lumen at three different locations. Mol. Reprod. Dev., v.63, p.96-103, 2002.

SHI, Y.; PULliAM, D.A.; LIU, Y.H. et al. Reduced mitochondrial ROS, enhanced antioxidant defense, and distinct age-related changes in oxidative damage in muscles of longlived Peromyscus leucopus. Am. J. Physiol. Reg., v.304, p.R343-R355, 2013.

STRZEZEK, R.; KOZIOROWSKA-GILUN, M.; KOWALOWKA, M.; STRZEZEK, J. Characteristics of antioxidant system in dog semen. Pol. J. Vet. Sci., v.12, p.55-60, 2009.

THOMASSEN, R.; FARSTAD, W. Artificial insemination in canids: a useful tool in breeding and conservation. Theriogenology, v.71, p.190199, 2009.

VERSTEGEN J, IGUER-OUADA M, ONCLIN $\mathrm{K}$. Computer assisted semen analyzers in andrology research and veterinary practice. Theriogenology. V.57, p. 149 - 179, 2002. 